We thank Professor Y W Kan for advice and encouragement; Dr B Forget and $\mathrm{Dr} \mathrm{T}$ Maniatis for $\alpha$ and $\beta$ globin probes; $\mathrm{S} \mathrm{H}$ Ho Foundation Ltd, Wideland Foundation Ltd, and Wu Chung Travelling Fellowship for financial support; and Messrs A Wong and C S Kwan for skilful technical work.

\section{References}

1 Ottolenghi S, Lanyon WG, Paul J, et al. The severe form of $\alpha$ thalassaemia is caused by a haemoglobin gene deletion. Nature 1974 ;251:389-91.

${ }^{2}$ Taylor JM, Dozy A, Kan YW, et al. Genetic lesion in homozygous $\alpha$ thalassaemia (hydrops fetalis). Nature 1974;251:392-4.

${ }^{3}$ Pressley L, Higgs DR, Clegg JB, Weatherall DJ. Gene deletions in $\alpha$ thalassemia prove that the 5 ' $\zeta$ locus is functional. Proc Natl Acad Sci USA 1980;77:3586-9.

4 Kattamis C, Metaxotou-Mavromati A, Tsiarta E, et al. Haemoglobin Barts hydrops syndrome in Greece. $B r$ Med $\mathcal{F} 1980 ; 281: 268-70$.

${ }^{5}$ Dozy AM, Kan YW, Embury SH, et al. $\alpha$-Globin gene organisation in blacks precludes the severe form of $\alpha$-thalassaemia. Nature $1979 ; 280$ : 605-7.

${ }^{6}$ Lie-Injo LE. Alpha-chain thalassemia and hydrops fetalis in Malaya : report of 5 cases. Blood 1962;20:581-90.
' Wasi P, Na-Nakorn S, Pootrakul S, et al. Alpha- and beta-thalassemia in Thailand. Ann NY Acad Sci 1969;165:60-82.

8 Wong V, Ma HK, Todd D, et al. Diagnosis of homozygous $\alpha$-thalassemia in cultured amniotic-fluid fibroblasts. $N$ Engl f Med 1978;298:669-70.

9 Dozy AM, Forman EN, Abuelo DN, et al. Prenatal diagnosis of homozygous $\alpha$-thalassemia. $\mathcal{F} A M A$ 1979;241:1610-2.

10 Kan YW, Trecartin RF, Dozy AM. Prenatal diagnosis of hemoglobinopathies. Ann NY Acad Sci 1980;344:141-50.

$1 \mathrm{Kan}$ YW, Dozy AM. Antenatal diagnosis of sickle-cell anaemia by DNA analysis of amniotic-fluid cells. Lancet 1978;ii:910-2.

12 Rigby PWJ, Dieckmann M, Rhodes C, Berg P. Labelling deoxyribonucleic acid to high specific activity in vitro by nick translation with DNA polymerase I. $\mathcal{f}$ Mol Biol 1977;113:237-51.

13 Wasi P, Na-Nakorn S, Pootrakul S. The $\alpha$ thalassaemias. Clin Haematol $1974 ; 3: 383-411$.

14 Todd D, Lai MCS, Braga CA, Soo HN. Alpha-thalassaemia in Chinese: cord blood studies. Br $\mathcal{F}$ Haematol 1969;16:551-6.

15 MRC Working Party on Amniocentesis. An assessment of the hazards on amniocentesis. Br $\mathcal{F}$ Obstet Gynaecol 1978;85, suppl 2.

16 Williamson R, Eskdale J, Coleman DV, et al. Direct gene analysis of chorionic villi: a possible technique for first-trimester antenatal diagnosis of haemoglobinopathies. Lancet 1981 ;ii:1125-9.

17 Ghosh A, Woo J, Liang ST, et al. Ultrasonic diagnosis of hydrops fetalis in the early second trimester. Aust NZ F Obstet Gynaecol 1983;23:108-9.

(Accepted 8 February 1984)

\title{
Fetal circulation during epidural analgesia for caesarean section
}

\author{
A LINDBLAD, K MARŠÁL， E VERNERSSON, H RENCK
}

\begin{abstract}
Fetal blood flow was examined during epidural analgesia in six women with uncomplicated pregnancies undergoing elective caesarean section. A non-invasive, ultrasonic technique was used to measure blood flow in the fetal descending aorta and intra-abdominal part of the umbilical vein before induction of analgesia with etidocaine and bupivacaine and 15 and 30 minutes afterwards. No appreciable change in fetal blood flow was observed.
\end{abstract}

\section{Introduction}

Lumbar epidural analgesia is being increasingly used for elective caesarean section. Among its advantages over general anaesthesia are the lack of drug induced respiratory depression of the newborn and the better preserved placental blood flow. ${ }^{1}$ Until now the fetal heart rate has been the only fetal circulatory variable to be controlled under obstetric analgesia. Recently, a non-invasive method of measuring fetal blood flow became available. ${ }^{2}$ We used this new method to evaluate possible effects of epidural analgesia on fetal circulation.

\footnotetext{
Department of Obstetrics and Gynaecology, General Hospital, S-214 01 Malmö, Sweden

A LINDBLAD, MD, senior registrar

K MARŚÁL, MD, senior lecturer

Department of Anaesthesia, General Hospital, Malmö

E VERNERSSON, MD, senior registrar

H RENCK, MD, professor

Correspondence to: Dr K Maršál.
}

\section{Patients and methods}

Fetal blood flow was examined in six women with uncomplicated pregnancies who were to be delivered by elective caesarean section. The indications for caesarean section were cephalopelvic disproportion in five cases and the age of the mother in one (she was a 42 year old primigravida). All of the women gave their informed consent.

The blood flow in the fetal descending aorta and the intra-abdominal part of the umbilical vein was examined with a $2 \mathrm{MHz}$ pulsed Doppler technique combined with real time B mode ultrasonography. ${ }^{2}$ The mean blood flow was calculated and the waveform of the maximum blood velocity analysed. The waveform was characterised by the pulsatility index (= (peak velocity -minimum velocity)/ mean velocity). ${ }^{3}$ The measurements were performed with the pregnant woman tilted slightly to the left $\left(15^{\circ}\right)$ to avoid hypotension. Fetal heart rate and the maternal pulse rate and blood pressure were also measured. Fetal blood flow was recorded before the induction of epidural analgesia and 15 and 30 minutes thereafter.

After preloading with 0.51 of a balanced electrolyte solution analgesia was induced at the L3-4 interspace using $10 \mathrm{ml}$ etidocaine $1.5 \%$ and $10-12 \mathrm{ml}$ bupivacaine $0.5 \%$ both containing adrenaline $(5 \mu \mathrm{g} / \mathrm{ml})$. Cutaneous analgesia up to the level of $\mathrm{T} 7$ and $\mathrm{T} 5$ ensued after 15 and 30 minutes, respectively.

The women were then delivered by caesarean section. The infants had a mean gestational age of 38.2 (SEM 0.3) weeks, a mean birth weight of 3388 (194) $\mathrm{g}$, a mean umbilical arterial $\mathrm{pH}$ of $7.22(0.02)$, and a mean umbilical venous $\mathrm{pH}$ of $7.28(0.02)$. The one minute Apgar score was $\geqslant 8$ in all of them.

\section{Results}

The table gives the mean values of the maternal and fetal circulatory variables. In no instance was the maternal systolic blood pressure lower than $100 \mathrm{~mm} \mathrm{Hg}$. The mean blood velocity and the diameters of the fetal aorta and umbilical vein were within the normal range before analgesia in all six fetuses and did not change during the study period. The figure shows the fetal aortic and umbilical blood flows; no appreciable change in fetal blood flow was observed. 
Mean (SEM) maternal and fetal circulatory variables before and 15 and 30 minutes after epidural analgesia $(n=6)$

\begin{tabular}{lccc}
\hline & $\begin{array}{c}\text { Control } \\
\text { period }\end{array}$ & $\begin{array}{c}15 \text { minutes } \\
\text { after }\end{array}$ & $\begin{array}{c}30 \text { minutes } \\
\text { after }\end{array}$ \\
\hline \multicolumn{4}{c}{ Maternal variables } \\
Systolic blood pressure (mm Hg) & $113(1 \cdot 7)$ & $108(3 \cdot 1)$ & $107(2 \cdot 5)$ \\
$\begin{array}{l}\text { Diastolic blood pressure (mm Hg) } \\
\text { Heart rate (beats/min) }\end{array}$ & $68(1 \cdot 7)$ & $56(3 \cdot)$ & $53(4 \cdot 2)$ \\
& $69(6 \cdot 1)$ & $75(4 \cdot 2)$ & $77(3 \cdot 1)$ \\
Heart rate (beats/min) & Fetal variables & & \\
Aortic pulsatility index & $125(1 \cdot 8)$ & $131(3.5)$ & $126(3 \cdot 4)$ \\
& $2 \cdot 1(0 \cdot 2)$ & $1 \cdot 9(0 \cdot 2)$ & $1 \cdot 9(0 \cdot 1)$ \\
\hline
\end{tabular}
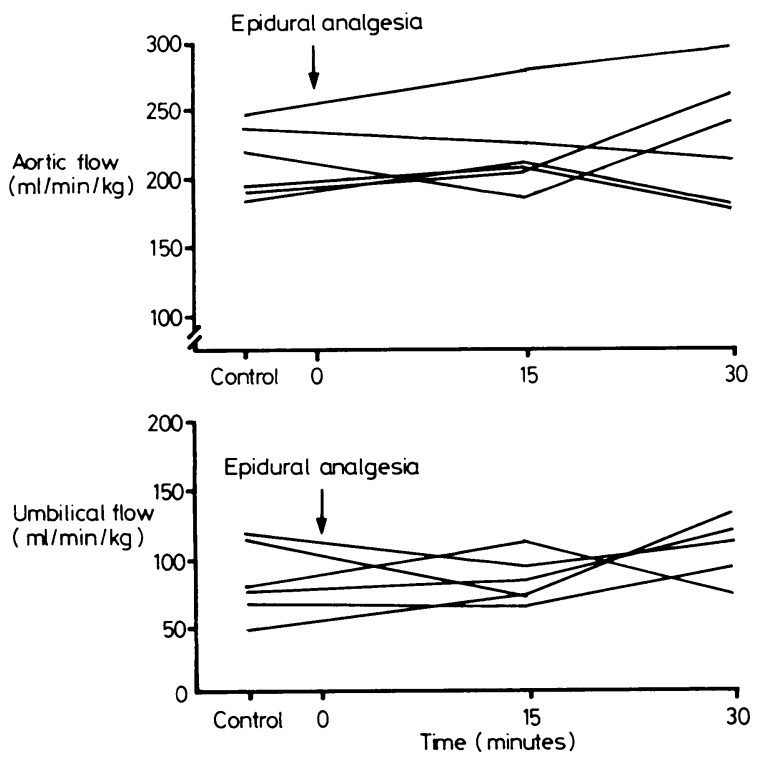

Fetal aortic and umbilical blood flow before and after epidural analgesia in six pregnancies. (One measurement of umbilical flow at 30 minutes is missing for technical reasons.)

\section{Discussion}

Local anaesthetics used for obstetric analgesia exert a direct negative inotropic effect on the fetal heart in in vitro experiments. ${ }^{4}$ The possible effects on fetal circulation in utero could previously be evaluated only by monitoring fetal heart rate or indirectly by assessing the condition of the newborn infant. The non-invasive method of measuring fetal blood flow used in the present study can detect changes in fetal cardiac output, as has been shown in fetuses with cardiac arrhythmias. ${ }^{5}$ In the present, preliminary report none of the fetal circulatory variables changed appreciably after the induction of epidural analgesia. These results indicate that epidural analgesia with etidocaine and bupivacaine does not affect the fetal circulation in normotensive mothers.

This ultrasonic method of measuring fetal blood flow provides a useful means of studying the influence of anaesthetic drugs or techniques, or both, on fetal circulation and can thereby help to make obstetric analgesia safer.

This study was supported by the Swedish Medical Research Council (grant No B84-17X-05980-04).

\section{References}

1 Jouppila R, Jouppila P, Hollmén A, et al. Effect of the anesthetic method, epidural and general anesthesia, on intervillous blood flow in cesarean sections. Regional Anesthesie 1977;2:2-8.

${ }^{2}$ Eik-Nes SH, Brubakk AD, U'stein MK. Measurement of human fetal blood flow. Br Med f 1980;280:283-4.

${ }^{3}$ McCallum WD. Fetal cardiac anatomy and vascular dynamics. Clin Obstet Gynecol $1981 ; 24: 837-49$.

4 Andersson KE, Gennser G, Nilsson E. Influence of mepivacaine on isolated human foetal hearts at normal and low pH. Acta Physiol Scand 1970;80, suppl 353:34-47.

${ }^{5}$ Maršál K, Eik-Nes SH, Lindblad A, Lingman G. Blood flow in the fetal descending aorta; intrinsic factors affecting fetal blood flow-that is, fetal breathing movements and cardiac arrhythmia. Ultrasound Med Biol (in press).

(Accepted 14 February 1984)

\title{
Bleeding oesophageal varices and hepatic dysfunction in adult polycystic kidney disease
}

\author{
P J RATCLIFFE，S REEDERS，J M THEAKER
}

\begin{abstract}
A patient with adult polycystic liver and kidney disease presented with haematemesis and melaena and was found to have raised serum creatinine, aspartate transaminase, and alkaline phosphatase values; hypoalbu-
\end{abstract}

John Radcliffe Hospital, Oxford OX3 9DU

P J RATCLIFFE, MRCP, medical registrar

$J$ M THEAKER, MA, MB, registrar in pathology

Renal Unit, Churchill Hospital, Oxford

$S$ REEDERS, MRCP, registrar

Correspondence to: Dr P J Ratcliffe. minaemia; and a prolonged prothrombin ratio. She also had oesophageal varices. With haemodialysis her aspartate transaminase activity fell to normal but she remained hypoalbuminaemic with a prolonged prothrombin ratio. She died after three weeks.

Although hepatic cysts do occur in adult polycystic kidney disease, they have been thought not to cause major liver disease. The hepatic cysts in this patient, however, did appear to be associated with portal hypertension and impaired hepatocellular function.

\section{Introduction}

A patient with autosomal dominant adult polycystic kidney disease had severe hepatic cystic disease associated with portal hypertension and hepatocellular dysfunction. Unusually extensive cystic hepatic disease was also seen in her daughter, who at the time had normal renal function. 